\title{
Application of mild-subcritical alkaline water extraction: optimum condition for phenolic antioxidant extracted from cold-pressed defatted KDML 105 rice bran and its phenolic profile
}

\author{
${ }^{1}$ Punnongwa, W., ${ }^{1}$ Sae-Eaw, A., ${ }^{1}$ Sripui, J. and ${ }^{1,2, *}$ Thawornchinsombut, S. \\ ${ }^{1}$ Department of Food Technology, Faculty of Technology, Khon Kean University, Khon Kaen, Thailand \\ 40002 \\ ${ }^{2}$ Cardiovascular Research Group, Khon Kaen University, Khon Kaen, Thailand
}

\begin{abstract}
Article history:
Received: 22 March 2021

Received in revised form: 30 April 2021

Accepted: 2 June 2021

Available Online: 26 January 2022
\end{abstract}

\section{Keywords:}

Subcritical alkaline water

extraction,

Response surface

methodology,

Antioxidant activity,

Phenolic profile

DOI:

https://doi.org/10.26656/fr.2017.6(1).195

\begin{abstract}
This research was aimed at optimizing the process of the mild-subcritical alkaline water (pH 9.5) extraction (mild SAW) of cold-pressed defatted Khao Dawk Mali 105 rice bran (CDRB) in order to achieve the maximum antioxidants with minimal brown colour. Response surface methodology and central composite design were performed with two variables: extraction temperature $\left(107-129^{\circ} \mathrm{C}\right)$ and time $(21-149$ mins). The elucidated optimum conditions were $119^{\circ} \mathrm{C}$ and 85 mins with predicted response values: the total phenolic content of $16.9 \mathrm{mg}$ gallic acid/g; protein of $64.3 \mathrm{mg} / \mathrm{g}$; an ABTS radical scavenging activity of $14.4 \mathrm{mg}$ Trolox $/ \mathrm{g}$; a browning index of 0.41 ; and reducing sugar of $62.0 \mathrm{mg} / \mathrm{g}$. Proto-catechuic acid and $p$-coumaric acid were major phenolic compounds in the CDRB, while trans-ferulic acid, proto-catechuic acid, and $p$-coumaric acid were all abundant in the mild SAW extract. The results confirmed that the mild SAW extraction process for antioxidants is an environmentally friendly approach, which can increase the release of value-added compounds from rice bran residues.
\end{abstract}

\section{Introduction}

In the year 2018, the annual production of rice in Thailand was 11.08 million tons (Thai Rice Exporters Association, 2019). Rice bran and defatted rice bran are co-products from the rice milling industry and the rice bran oil industry, respectively. These co-products contain high nutritional and bioactive compounds, such as hypoallergenic protein, phytosterols, $\alpha$-tocopherol, tocotrienol, $\gamma$-oryzanol, $\gamma$-aminobutyric acid (GABA), polyphenols, and triterpene alcohol (Li et al., 2012). Various phenolic compounds are found in rice bran, such as caffeic acid, ferulic acid, tannins, catechuic acid, sinapic acid, hydroxybenzoic acid, syringic acid, $p$ coumaric acid, and quercetin, as well as in rice (i.e., kaempferol, naringin, rutin, and catechin) (Tian et al., 2004; Shao et al., 2014; Setyaningsih et al., 2016). Most of these compounds have antioxidant properties, such as lipid peroxidation prevention; free radicals (i.e., hydroxyl, DPPH and ABTS) scavenging activities, and ferric reducing antioxidant power (FRAP) (Zhang et al., 2010; Sompong et al., 2011; Wataniyakul et al., 2012). Therefore, researchers have attempted to extract these active compounds from rice bran. In many cases, a coproduct, which has been derived from the food industry, has experienced severe processing conditions (i.e., high temperature, solvent, low or high $\mathrm{pH}$, and high salts), which causes complexity of components, thus obstructing the release of active compounds during the extraction process. For the purpose of isolating bioactive components, subcritical water extraction (SWE) or pressurized hot water extraction is an alternative method to conventional solvent extraction. This technique uses hot water $\left(100\right.$ and $\left.374^{\circ} \mathrm{C}\right)$ under pressure to sustain its liquid state (the critical point of water, $374^{\circ} \mathrm{C}$ and 22.4 $\mathrm{MPa}$ ). Under these subcritical conditions, water contains more ion products, which considerably increase with temperature. Accordingly, subcritical water can enhance chemical reactions, such as hydrolysis (Wiboonsirikul et al., 2008; Pourali et al., 2009). Moreover, the dielectric constant of the subcritical water decreases to that of the polar organic solvents with the increasing temperature (Jin, 2014). Thus, numerous active components from biomaterials can be efficiently released. Additionally, the SWE is a clean technology without the need for chemicals. Therefore, it has been applied to various plant materials, including defatted rice bran to produce various active compounds (Fabian et al., 2007; Pourali et al., 2009; Munir et al., 2018). RSM is a useful technique that 
is often applied to optimize the extraction conditions for chemicals and biochemical compounds from natural sources (Bas et al., 2007). The optimization of the SWE of the bioactive compounds from wheat bran was performed using response surface methodology (RSM) (Liyana-Pathirana and Shahidi, 2005). A recent study by Kaewjumpol et al. (2018) revealed that using a sequence of mild-subcritical alkaline water (mild SAW) extraction, which is then followed by protease hydrolysis, can enhance the release of active compounds from industrially defatted rice bran (IDRB, defatted by hexane). The RSM was employed to optimize the proteolysis conditions (enzyme concentration and hydrolysis time) to obtain maximal protein and antioxidant properties. The optimal proteolysis conditions were achieved at $20 \mathrm{~mL} / \mathrm{kg}$ IDRB (enzyme/ substrate ratio) for $6 \mathrm{hrs}$. Higher yields and protein recovery ( $\sim 4.8$ times) were reported when compared to the conventional alkaline extraction. Six phenolic acids were identified in the freeze-dried rice bran hydrolysate (RBH) with distinct amounts of $p$-coumaric and ferulic acids. Nevertheless, using a relatively harsh SAW condition ( $\mathrm{pH} 9.5,130^{\circ} \mathrm{C}$ for 120 mins), a rice bran hydrolysate $(\mathrm{RBH})$ with brown colour was obtained. In this study, a Khao Dawk Mali 105 (KDML 105) rice bran defatted by a different method called "cold press" (without solvent) was used as a raw material. The cold press method has typically been employed in a rice bran oil capsule and a premium grade cooking oil manufacturer for consumers who demand healthy food products. This research aimed at investigating the optimized conditions of mild-subcritical alkaline water extraction of cold-pressed defatted KDML 105 rice bran (CDRB) by providing the maximum antioxidant activity with a minimum of brown colour extract using response surface methodology (RSM). The phenolic profiles of the CDRB and the extract were also elucidated.

\section{Materials and methods}

\subsection{Rice bran sample}

A Khao Dawk Mali 105 (KDML 105) rice bran was collected from the Kasetsin Golden Rice Co., Ltd., Khon Kaen, Thailand within $1 \mathrm{hr}$ after milling. The rice bran was packed in a polyethylene plastic bag and was transferred to the Department of Food Technology Laboratory, Khon Kaen University, Khon Kaen within 1 hr. The rice bran was stabilized within $2 \mathrm{hrs}$ after arriving by autoclaving at $121^{\circ} \mathrm{C}$ for 15 mins and then drying at $60^{\circ} \mathrm{C}$ in a hot air oven for $7 \mathrm{hrs}$ (moisture content $\sim 7 \%$ ). The sample was sifted through an 80 mesh sieve. The $<80$ mesh stabilized $C D R B$ was vacuum packed in an aluminium foil bag and kept at $-20^{\circ} \mathrm{C}$ until analysed.

\subsection{Chemicals and reagents}

All testing chemicals, consisting of sodium potassium phosphate $\left(\mathrm{NaH}_{2} \mathrm{PO}_{4}\right)$, potassium hydrogen phosphate $\left(\mathrm{KH}_{2} \mathrm{PO}_{4}\right)$, sodium chloride $(\mathrm{NaCl})$, potassium chloride $(\mathrm{KCl})$, potassium persulfate, Folin-Ciocalteu reagent, 6-hydroxy-2,5,7,8-tetramethylchromane-2carboxylic acid (Trolox), 2,4,6-tris(2-pyridyl)-s-triazine (TPTZ), 2,2'-azino-bis(3-ethylbenzothiazoline-6sulfonic acid) diammonium salt (ABTS), potassium carbonate, concentrated $\mathrm{HCl}$ acid, glacial acetic acid, formic acid, acetonitrile, sodium potassium tartrate tetrahydrate, bovine serum albumin, and borate were all analytical grade. The Protease G6 (Dupont), a commercial bacterial alkaline protease was obtained from Siam victory chemical, Co. Ltd. The phenolic acid standards, methanol, and acetonitrile were HPLC grade.

\subsection{Sample preparation}

The stabilized rice bran was defatted by the cold press method (Screw press, March Cool Industry Co., Ltd., Thailand) to obtain the cold-pressed defatted rice bran (CDRB). The CDRB was vacuum packed in an aluminium foil bag and kept at $-20^{\circ} \mathrm{C}$ until tested.

Proximate compositions of the CDRB were determined (AOAC, 2000). The moisture, protein, fat, fibre, ash, and carbohydrate contents were $4.42 \pm 0.33 \%$, $14.72 \pm 0.54 \%, 3.61 \pm 0.46 \%, 34.91 \pm 0.37 \%, 2.38 \pm 0.40 \%$, and $39.96 \pm 0.68 \%$, respectively.

\subsection{Optimization of mild subcritical alkaline water extraction conditions}

Rice bran extracts were prepared in accordance with Kaewjumpol et al. (2018) with some modifications. The suspension of CDRB in distilled water (1:7) was soaked for $18 \mathrm{hrs}$ at $4{ }^{\circ} \mathrm{C}$. The mixture was adjusted to a $\mathrm{pH}$ of 9.5 by using $1 \mathrm{M} \mathrm{NaOH}$ and then was placed in an autoclave (ES-315, Tomy Kogyo Co., Ltd, Tokyo, Japan) under the mild-subcritical alkaline (mild SAW) conditions. Variable effects of temperature $\left(107-129^{\circ} \mathrm{C}\right)$ and reaction time (21-149 mins) were analysed using RSM to determine the optimal conditions for the mild SAW process. Two variables (i.e., the reaction time $\left(x_{1}\right)$ and the temperature $\left(x_{2}\right)$ of the mild SAW) at five variable code levels were applied according to the central composite design (CCD) (Table 1). Thirteen experiments of combinations of independent variables were obtained (Table 2). Meanwhile, the other variables were fixed. The upper and lower levels of extraction time and temperature were selected based on the preliminary experimental results, as well as the limitations of the equipment (autoclave). The sample was immediately cooled to room temperature for approximately 30 mins. After centrifugation at $10,000 \times g$ for $10 \mathrm{mins}$, the 
supernatant (mild SAW extract, SAWE) was freezedried and stored at $-20^{\circ} \mathrm{C}$ until it was analysed. The SAWE powder was dissolved in an appropriate solvent and concentration for each analytical method. The responses $(\mathrm{Y})$, which consisted of the total phenolic content (TPC), the protein content, the ABTS scavenging activity, the ferric reducing antioxidant power (FRAP), the browning index, the reducing sugar content, and the yields of the extracts were all determined. The following Equation (1) demonstrates the regression model between the dependent variables $(\mathrm{Y})$ and the independent variables $(\mathrm{x})$ :

$Y=\beta_{0}+\beta_{1} x_{1}+\beta_{2} x_{2}+\beta_{11} x_{1}^{2}+\beta_{22} x_{2}^{2}+\beta_{12} x_{1} x_{2}$

Where $\beta_{0}, \beta_{1}$ and $\beta_{2}, \beta_{11}$ and $\beta_{22}$, as well as $\beta_{12}$ are the regression coefficients for the intercept, linear, quadratic, and interaction terms, respectively.

Table 1. Independent variables and levels of central composite design applied to the mild SAW conditions.

\begin{tabular}{|c|c|c|c|c|c|c|}
\hline \multirow{2}{*}{\multicolumn{2}{|c|}{$\begin{array}{l}\text { Independent variables } \\
\text { Code }\end{array}$}} & \multicolumn{5}{|c|}{ Levels } \\
\hline & & $-\alpha$ & 1 & 0 & 1 & $+\alpha$ \\
\hline$x_{1}$ & & 21 & 40 & 85 & 130 & 149 \\
\hline$x_{2}$ & Temperature $\left({ }^{\circ} \mathrm{C}\right)$ & 107 & 110 & 118 & 126 & 129 \\
\hline
\end{tabular}

The experimental data were fitted into the secondorder polynomial equations and the regression coefficients were calculated. Analysis of variance (ANOVA) was conducted to evaluate the significance of the coefficients of the models. The lack of fit was tested to determine the adequacy of the model to fit the experimental data. If an insignificant lack of fit $(p>$ 0.05) was observed for the response, the model, therefore, was shown to adequately fit the experimental data. The significant ( $p$-value) regression coefficient in a model suggested a significant effect on the response variables (Yang and Wang, 2012). By using the regression coefficients, 3-D surface plots and contour plots were created from the fitted polynomial equation.

\subsection{Verification of the model}

The SAWE powder was produced using the optimal mild SAW extraction conditions to determine the validity of the model. The response variables of the obtained SAWE were analysed and calculated for the coefficient variation and were compared to the predicted values.

\subsection{Proximate compositions}

In accordance with the method of the Association of Official Analytical Chemists (AOAC, 2000), proximate analysis was conducted to determine the moisture content, protein, fat, fibre, ash, and carbohydrate components of the SAWE powder.

\subsection{Total phenolic content (TPC)}

The total polyphenols (Yodmanee et al., 2011) of the rice bran SAWE were assayed using the Folin-Ciocalteu method. Briefly, the Folin-Ciocalteu reagent was diluted with water to a ratio of $1: 9(\mathrm{v} / \mathrm{v})$, and then $200 \mu \mathrm{L}$ of the SAWE solution was added to $2.5 \mathrm{~mL}$ of this reagent. The mixture was incubated at room temperature for two minutes, and then $2 \mathrm{~mL}$ of sodium carbonate solution (75 $\mathrm{g} / \mathrm{L}$ ) was mixed. The mixture was incubated for $120 \mathrm{~min}$ in a dark room, and then its absorbance was measured at $765 \mathrm{~nm}$ using a spectrophotometer (UV 1800 Shimadzu, Co. Ltd., Kyoto, Japan). The total phenolic content was determined using gallic acid as the standard.

\subsection{Protein content by Lowry-Folin assay}

The protein content of the rice bran SAWE was determined by the Lowry-Folin assay (Lowry, 1951). Absorbance at $750 \mathrm{~nm}$ of the reaction solution was measured against a blank containing deionized water,

Table 2. Coded values and valid values of two independent variables of mild SAW conditions in the central composite design.

\begin{tabular}{ccccc}
\hline $\begin{array}{c}\text { Run } \\
\text { order }\end{array}$ & $\begin{array}{c}\text { Code value } 1 \\
\left(x_{1}\right) \\
(\text { Time })\end{array}$ & $\begin{array}{c}\text { Code value } 2 \\
\left(x_{2}\right)\end{array}$ & $\begin{array}{c}\text { Factor } 1 \\
\left(x_{1}\right)\end{array}$ & $\begin{array}{c}\text { Factor } 2 \\
\left(x_{2}\right)\end{array}$ \\
\hline 1 & -1.414 & 0 & 21 & 118 \\
$($ Temperature $)$ & (Timemperature, $\left.{ }^{\circ} \mathrm{C}\right)$ \\
2 & 0 & -1.414 & 85 & 107 \\
3 & 0 & 0 & 85 & 118 \\
4 & 0 & 0 & 85 & 118 \\
5 & -1 & -1 & 40 & 110 \\
6 & -1 & +1 & 40 & 126 \\
7 & 0 & 0 & 85 & 118 \\
8 & +1 & -1 & 130 & 110 \\
9 & 0 & +1.414 & 85 & 129 \\
10 & +1.414 & 0 & 148 & 118 \\
11 & +1 & +1 & 130 & 126 \\
12 & 0 & 0 & 85 & 118 \\
13 & 0 & 0 & 85 & 118 \\
\hline
\end{tabular}


while the protein content was determined by using standard bovine serum albumin (BSA).

\subsection{ABTS scavenging activity}

The ABTS radical scavenging activity of the rice bran SAWE was measured by using a method adapted from Thaipong et al. (2006). The stock solutions of 2 $\mathrm{mM}$ of ABTS solution and $70 \mathrm{mM}$ potassium persulfate solution were prepared. The working solution was then prepared by mixing the two stock solutions and then incubating the solution for $24-48 \mathrm{hrs}$ at room temperature in a dark room. The solution was diluted by mixing the ABTS solution with a $0.1 \mathrm{M}$ phosphate buffer solution added with $\mathrm{NaCl}(0.818 \%)$ and $\mathrm{KCl}(0.0015 \%)$ at a $\mathrm{pH}$ of $7.4(1: 6 \mathrm{v} / \mathrm{v})$. Approximately, $0.1 \mathrm{~mL}$ SAWE and 3 $\mathrm{mL}$ ABTS solution were mixed and kept in dark conditions for 6 mins. Absorbance at $734 \mathrm{~nm}$ was read using the UV 1800 Shimadzu spectrophotometer. For each assay, fresh ABTS solution was prepared. The standard curve was linear between $0-50 \mu \mathrm{g}$ of Trolox equivalent (TE).

\subsection{Ferric reducing antioxidant power (FRAP assay)}

The FRAP assay determines the ability of an antioxidant to reduce $\mathrm{Fe}^{3+}$ to $\mathrm{Fe}^{2+}$. The FRAP of the SAW extract was monitored by following the method by Thaipong et al. (2006). The stock solution was comprised of $300 \mathrm{mM}$ acetate buffer ( $\mathrm{pH} 3.6), 10 \mathrm{mM}$ TPTZ solution in $40 \mathrm{mM} \mathrm{HCl}$, and $20 \mathrm{mM} \mathrm{FeCl}{ }_{3} \cdot 6 \mathrm{H}_{2} \mathrm{O}$ solution. The fresh working solution was prepared by mixing $25 \mathrm{~mL}$ of acetate buffer, $2.5 \mathrm{~mL}$ of TPTZ solution, and $2.5 \mathrm{~mL}$ of $\mathrm{FeCl}_{3} \cdot 6 \mathrm{H}_{2} \mathrm{O}$ solution and then warming the solution at $37{ }^{\circ} \mathrm{C}$ before using. The FRAP solution $(4.75 \mathrm{~mL})$ was added with $0.25 \mathrm{~mL}$ SAWE. After 30 min under dark conditions, the absorbance of the coloured product [ferrous tripyridyltriazine complex] was read at $593 \mathrm{~nm}$. Trolox was used as the standard with a linearity range between 0 and $50 \mu \mathrm{g}$.

\subsection{Browning index}

To measure the degree of browning by colour development due to the Maillard browning reaction during subcritical alkaline water extraction, the absorbance of the diluted SAWE (SAWE: distilled water $=1: 50,0.02 \mathrm{~g} / \mathrm{mL}$ ) was measured at $420 \mathrm{~nm}$ (Dong et al., 2011) with slight modifications. The browning index was the absorbance determined from a diluted sample.

\subsection{Reducing sugar content}

The reducing sugar content of the SAWE was determined according to the method by Nelson Somogyi (1952). A low-alkalinity copper reagent (Somogyi reagent, Solution A) and copper reagent (Nelson reagent,
Solution B) were prepared according to Nelson (1944) and Somogyi (1952). Approximately $1 \mathrm{~mL}$ of the SAWE solution was mixed with $1 \mathrm{~mL}$ of the low-alkaline Somogyi reagent (solution A), and heated in a boiling water bath for $10 \mathrm{~min}$. After cooling in an ice bath, the chromogenic reagent, $1 \mathrm{~mL}$ Nelson's reagent, was added and incubated for $15 \mathrm{mins}$, and then $10 \mathrm{~mL}$ of distilled water was added. The absorbance was measured at 500 $\mathrm{nm}$. Glucose was used for the standard curve preparation.

\subsection{Yield}

The yield of the rice bran, which had been extracted using the mild SAW treatment, was calculated by the following equation:

Yield $(\%)=[($ weight of freeze-dried SAWE powder $) \times$ $100] /$ weight of defatted rice bran used.

\subsection{Extraction of the phenolic compounds for identification and quantification}

The identification and quantification of the CDRB and its SAWE powder were compared to reveal the effects of the extraction process on the phenolic compounds. The extraction method of phenolic compounds described by Shao et al. (2014) was employed, and to that method, slight modifications were made. Concisely, the CDRB and SAWE powder were extracted with $100 \mathrm{~mL}$ of $80 \%$ methanol with ultrasonication for $30 \mathrm{mins}$ at $40^{\circ} \mathrm{C}$. After centrifugation at $10,000 \times g$ for $10 \mathrm{mins}\left(4^{\circ} \mathrm{C}\right)$, the residue was repeatedly extracted and the supernatants were pooled. Then the supernatant was adjusted to a $\mathrm{pH}$ value of $\sim 1.5-2.0$ using $2 \mathrm{M} \mathrm{HCl}$ acid and was concentrated using a rotary evaporator (Buchi R124, B480, Japan) at $50^{\circ} \mathrm{C}$. Next, the fat in the concentrate was removed by $30 \mathrm{~mL}$ of hexane three times and then was extracted with $30 \mathrm{~mL}$ of ethyl acetate three times. The ethyl acetate extracts were collected and evaporated by rotary evaporation at $35^{\circ} \mathrm{C}$ until dry. The crude free phenolic extract was prepared by adding $5 \mathrm{~mL}$ of $80 \%$ methanol to dissolve the dried extract.

\subsection{The analysis of phenolic compounds by Ultra-} performance liquid chromatography (UPLC)

The phenolic compounds in the crude free phenolic extract were analysed by using AcquityTM Ultra Performance Liquid Chromatography coupled with a photodiode array (PDA) detector (Water Corporation, USA) adapted from Vichapong et al. (2010) and Shao et al. (2014). A guard-column (Waters, symmetry C18, 5 $\mu \mathrm{m}, 3.9 \times 20 \mathrm{~mm})$ and a $5 \mu \mathrm{m}$ symmetry $\mathrm{C} 18$ column $(150 \times 4.6 \mathrm{~mm})$ were used for separation. The sample was filtered through a $0.2 \mu \mathrm{m}$ nylon microfilter membrane (Whatman) before being injected by an autosampler at a 
$10 \mu \mathrm{L}$ injection volume. The mobile phase contained A $(0.1 \%$ acetic acid in deionized water) and $\mathrm{B}$ (acetonitrile; $\mathrm{ACN}$ ) with a $0.8 \mathrm{~mL} / \mathrm{min}$ flow rate. The initial mobile phase composition was $7 \% \mathrm{ACN}$, which was ramped to $15 \%$ ACN (0-10 mins), and then was ramped to $35 \%$ ACN (10-15 mins). Next, it was ramped to $55 \%$ ACN (15-20 mins), and after that, it was finally ramped to $100 \%$ ACN (20-25 mins) and held for 15 mins for washing the column. The phenolic acids were measured at a wavelength of $280 \mathrm{~nm}$. External calibration curves were applied in order to determine the content of the phenolic acids, which were identified by a spike of standard phenolic compounds.

\subsection{Statistical analysis}

Central composite design (CCD) was conducted using the Design-Expert software version 6.0 (Stat-Ease, Inc., Minneapolis, MN, USA). ANOVA, while the significant differences between means were determined using Duncan's multiple range test $(\mathrm{P}<0.05)$ and were carried out using the SPSS statistics program (Version 19) for Windows (SPSS Inc., Chicago, IL, USA). All tests were conducted in duplicate.

\section{Results and discussion}

\subsection{Optimization of SAW conditions for rice bran SAWE production.}

The SAW extraction time $\left(x_{1}, 21-149 \mathrm{~min}\right)$ and temperature $\left(x_{2}, 107-129^{\circ} \mathrm{C}\right)$ were optimized using RSM in order to achieve the maximum antioxidant activity, but the minimal brown colour of the SAW extract (SAWE) from CDRB. The SAWE powders demonstrated the antioxidant properties, including the TPC, the ABTS radical scavenging activity, and the FRAP, which varied from 8.45 to $19.36 \mathrm{mg} \mathrm{GAE} / \mathrm{g}$, from 7.37 to $16.17 \mathrm{mg}$ Trolox equivalent (TE) $/ \mathrm{g}$, and from 0.30 to $1.14 \mathrm{mg} \mathrm{TE} / \mathrm{g}$, respectively. Furthermore, the protein content, reducing sugar content, browning index, and the yield of SAWE powder was in the range of 28.74 to $83.45 \mathrm{mg} / \mathrm{g}, 16.50-84.58 \mathrm{mg} / \mathrm{g}, 0.365-0.849$ (A 420 ), and $31.03-38.96 \%$, respectively (Table 3 ).

The regression coefficients and analyses of the variance of the second-order polynomial models for the responses of rice bran SAWE are summarized in Table 4. The second-order polynomial models represented the experimental data of most of the responses, except for the protein content, which was adequately represented by the linear model. The insignificant lack of fit $(p>0.05)$ indicated that the models were adequately fit the experimental data. However, the significant lack of fit ( $\mathrm{p}$ $=0.0183)$ of the Yield $\left(Y_{7}\right)$ was noted. All models of responses indicated that the $\mathrm{P}$ values were lower than 0.05 (except for that of FRAP $\left(Y_{4}\right)(\mathrm{p}=0.1857)$, which suggested that the model was adequately represented the experimental data. The adjusted $\mathrm{R}$ squared $\left(\mathrm{R}^{2}{ }_{\text {adj }}=\right.$ 0.3071) of the model of the FRAP was low, which revealed a low determination fitting coefficient. These results of ANOVA suggested that the model of the FRAP was not reliable and accurate and that the model of the Yield was not adequately fit. The coefficient of multiple determinations $\left(\mathrm{R}^{2}\right)$ for the total phenolic content, protein content, ABTS, browning index, and reducing sugar were $0.8996,0.5474,0.7102,0.9941$, and 0.7335 , respectively. The data in Table 4 demonstrates that the models were able to explain the results by $89.96 \%, 57.74 \%, 71.02 \%, 99.41 \%$, and $73.35 \%$, respectively.

\subsection{Total phenolic content (TPC)}

The response surface and contour plots of the experimental values of the phenolic compounds are presented in (Figures 1A, 2A) and in Table 4. The extraction time $\left(x_{1}\right)$ had significant positive linear and negative quadratic effects $(\mathrm{p}<0.05)$ on the TPC. A significant interaction effect between the extraction time $\left(x_{1}\right)$ and the temperature $\left(x_{2}\right)$ was also observed (Table 4). The TPC had increased along the extended time when the extraction temperature was low $\left(\sim 110^{\circ} \mathrm{C}\right)$ while increasing and then decreasing at higher extraction temperatures (Figure 1A). At lower temperature conditions, subcritical alkaline water may have enhanced the release of free phenolic compounds from their bound form. The decrease in phenolic content could probably have been due to phenolic decomposition at higher extraction temperatures (Wataniyakul et al., 2012; Belwal et al., 2016). Wataniyakul et al. (2012) examined the microwave pre-treatment of defatted rice bran for the enhanced recovery of total phenolic compounds extracted by subcritical water extraction. The study found that the total phenolic yields of the extracts had slightly increased as the pre-treatment temperature was increased from 60 to $80^{\circ} \mathrm{C}$ given that phenolic acids are released from the bran by hydrolysis of the rice bran cell wall. This was because the polarity of water at a subcritical condition is reduced to those of some organic solvents (Ko et al., 2014). Organic solvents such as methanol and ethanol are typically used as a medium for polyphenolic compounds extraction. Kaewjumpol et al. (2018) revealed that $70 \%$ methanol could dissolve the highest TPC content from the SAW extract of the industrially DRB.

\subsection{Protein content}

The response surface analysis (RSA) and the equation (Table 3 and Table 4) demonstrated that the relationship between the protein content and the extraction parameters did not fit well with the quadratic 
Table 3. Actual levels of two independent variables (x) of central composite design and response values (Y) of subcritical alkaline water extract (SAWE) powders from defatted rice bran.

\begin{tabular}{|c|c|c|c|c|c|c|c|c|c|}
\hline$\underset{\Xi}{\beth}$ & $\begin{array}{c}x_{1} \\
\text { Time } \\
(\min )\end{array}$ & $\begin{array}{c}x_{2} \\
\text { Temperature } \\
\left({ }^{\circ} \mathrm{C}\right)\end{array}$ & $\begin{array}{c}Y_{1} \\
\text { Total } \\
\text { phenolic } \\
\text { content } \\
(\mathrm{mg} \mathrm{GAE} / \mathrm{g})\end{array}$ & $\begin{array}{c}Y_{2} \\
\text { Protein } \\
(\mathrm{mg} / \mathrm{g})\end{array}$ & $\begin{array}{c}Y_{3} \\
\text { ABTS } \\
(\mathrm{mg} \text { Trolox } / \mathrm{g})\end{array}$ & $\begin{array}{c}Y_{4} \\
\text { FRAP } \\
(\mathrm{mg} \text { Trolox/g) }\end{array}$ & $\begin{array}{c}Y_{5} \\
\text { Browning } \\
\text { index } \\
\text { (A240) }\end{array}$ & $\begin{array}{c}Y_{6} \\
\text { Reducing } \\
\text { sugar (mg/g) }\end{array}$ & $\begin{array}{c}Y_{7} \\
\text { Yield } \\
(\%)\end{array}$ \\
\hline 1 & 21 & 118 & 8.45 & 28.74 & 10.67 & 0.58 & 0.365 & 84.58 & 33.02 \\
\hline 2 & 85 & 107 & 17.92 & 72.77 & 12.16 & 0.87 & 0.623 & 16.5 & 34.93 \\
\hline 3 & 85 & 118 & 17.48 & 79.49 & 12.49 & 1.14 & 0.411 & 64.37 & 38.07 \\
\hline 4 & 85 & 118 & 17.6 & 80.75 & 14.97 & 1.02 & 0.402 & 56.41 & 38.96 \\
\hline 5 & 40 & 110 & 8.91 & 32.52 & 7.37 & 0.3 & 0.387 & 27.11 & 31.03 \\
\hline 6 & 40 & 126 & 14.53 & 68.66 & 13.95 & 0.64 & 0.528 & 66.26 & 36.55 \\
\hline 7 & 85 & 118 & 17.9 & 72.77 & 15.19 & 1.14 & 0.411 & 56.41 & 38.57 \\
\hline 8 & 130 & 110 & 19.36 & 87.06 & 12.88 & 1.05 & 0.825 & 29.63 & 31.7 \\
\hline 9 & 85 & 129 & 15.37 & 41.26 & 16.17 & 0.47 & 0.715 & 69.3 & 35.65 \\
\hline 10 & 149 & 118 & 15.62 & 83.45 & 13.00 & 0.68 & 0.845 & 49.09 & 34.29 \\
\hline 11 & 130 & 126 & 15.29 & 69.99 & 14.2 & 0.94 & 0.849 & 54.52 & 36.76 \\
\hline 12 & 85 & 118 & 15.85 & 72.82 & 12.71 & 0.81 & 0.388 & 69.42 & 38.57 \\
\hline 13 & 85 & 118 & 15.85 & 54.24 & 15.27 & 0.77 & 0.395 & 49.21 & 37.46 \\
\hline
\end{tabular}
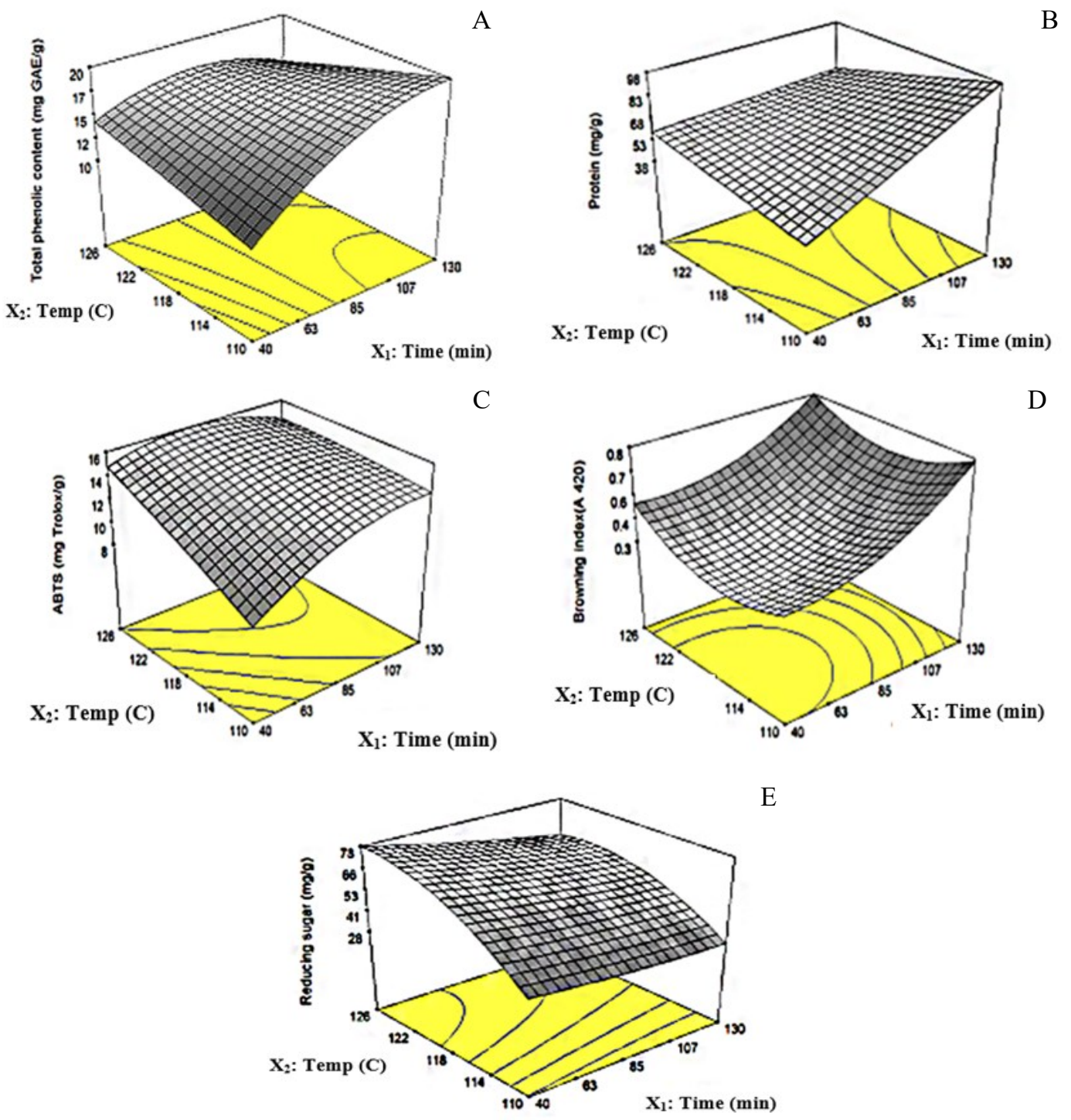

Figure 1. Response surface plots revealing effect of $x_{1}$, time and $x_{2}$, temperature of mild SAW conditions on A: total phenolic content, B: protein content, C: ABTS, D: browning index, and E: reducing sugar 
Table 4. The fitted quadratic models (code variable terms) for responses (phenolic compounds, protein, ABTS, FRAP, browning index and reducing sugar).

\begin{tabular}{|c|c|c|c|c|}
\hline Responses & Regression equation & Model P value & Lack of fit & Adjusted $\mathrm{R}^{2}$ \\
\hline Phenolic & $\begin{array}{l}Y_{1}=16.94+2.67 x_{1}{ }^{*}-0.26 x_{2}-2.40 x_{1}{ }^{2 *}-0.10 x_{2}{ }^{2}- \\
2.42 x_{1} x_{2}{ }^{*}{ }^{*}\end{array}$ & 0.0024 & 0.4251 & 0.8996 \\
\hline Protein & $Y_{2}=64.96+16.66 x_{1}^{*}-3.19 x_{2}-13.30 x_{1} x_{2}$ & 0.017 & 0.2682 & 0.5474 \\
\hline ABTS & $\begin{array}{l}Y_{3}=14.13+1.13 x_{1}{ }^{*}+1.70 x_{2}{ }^{*}-1.37 x_{1}{ }^{2 *}-0.20 x_{2}{ }^{2}- \\
1.32 x_{1} x_{2}\end{array}$ & 0.0125 & 0.6954 & 0.7102 \\
\hline FRAP & $\begin{array}{l}Y_{4}=0.98+0.15 x_{1}-0.04 x_{2}-0.15 x_{1}^{2}-0.13 x_{2}^{2}- \\
0.11 x_{1} x_{2}\end{array}$ & 0.1857 & 0.2327 & 0.3071 \\
\hline Browning index & $\begin{array}{l}Y_{5}=0.40+0.18 x_{1}{ }^{*}+0.037 x_{2}{ }^{*}+0.10 x_{1}^{2^{*}}+0.14 \\
x_{2}^{2^{*}-0.029 x_{1} x_{2}{ }^{*}}\end{array}$ & $<0.0001$ & 0.1134 & 0.9941 \\
\hline Reducing sugar & $\begin{array}{l}Y_{6}=59.17-7.43 x_{1}+17.34 x_{2}^{*}+1.21 x_{1}^{2}-10.76 \\
x_{2}^{2 *}-3.57 x_{1} x_{2}\end{array}$ & 0.0095 & 0.2084 & 0.7335 \\
\hline Yield & $\begin{array}{l}Y_{7}=38.33+0.33 x_{1}+1.45 x_{2}{ }^{*}-2.45 x_{1}{ }^{2 *}-1.63 x_{2}{ }^{2 *}- \\
0.11 x_{1} x_{2}\end{array}$ & 0.0097 & 0.0183 & 0.732 \\
\hline
\end{tabular}

Note: * Significant at $\mathrm{p}<0.05$

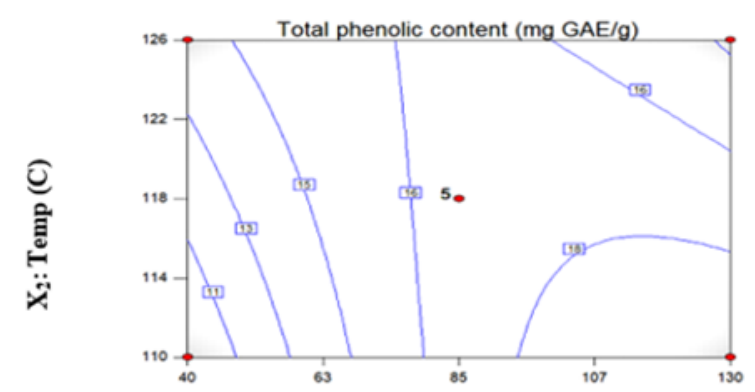

A

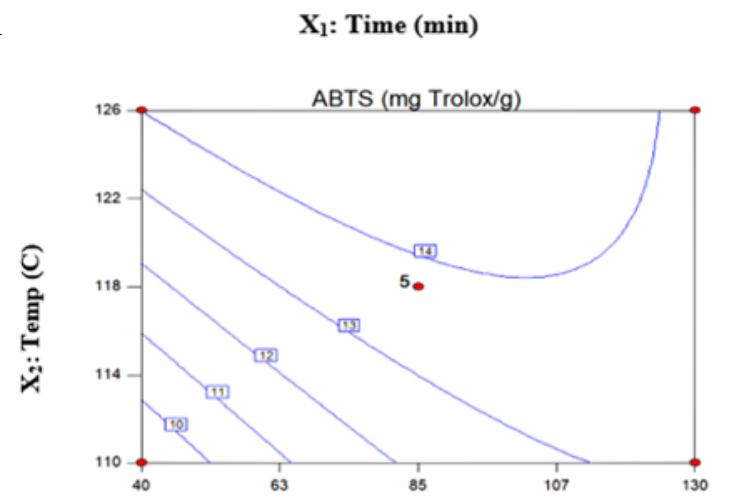

$\mathrm{C}$

$\mathrm{X}_{1}$ : Time (min)
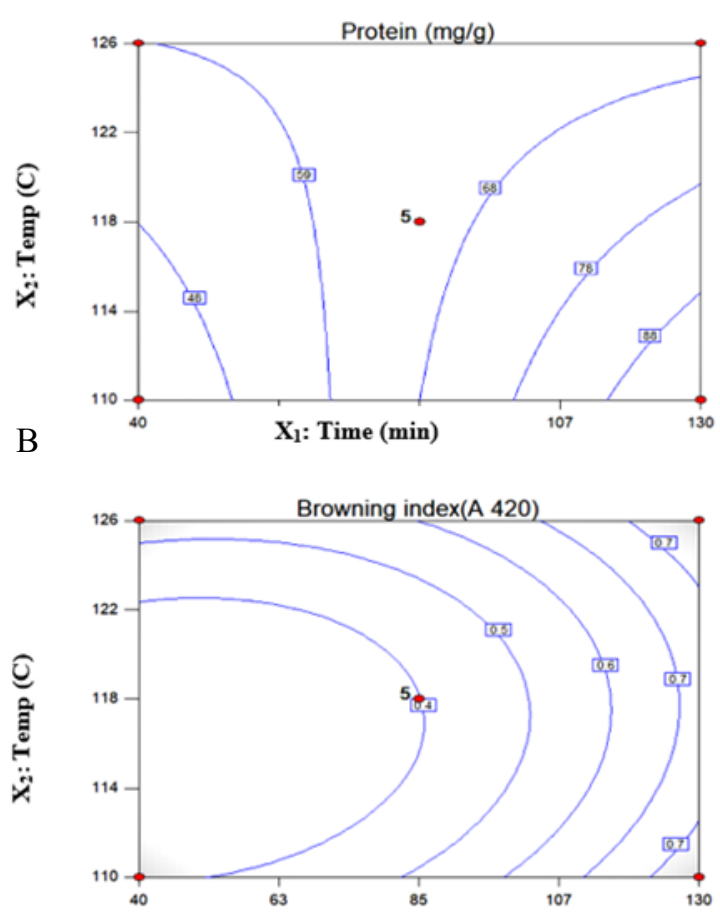

$\mathrm{D}$

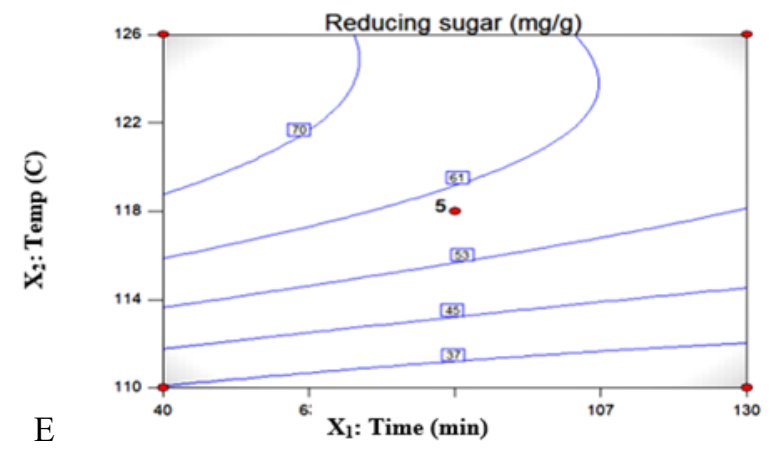

Figure 2. The contour plots for the effect of $x_{1}$, time and $x_{2}$, temperature of mild SAW conditions on A: total phenolic content, B: protein content, C: ABTS, D: browning index, and E: reducing sugar.

$\left(\mathrm{R}^{2}=0.5474\right)$. For both variables, no significant the protein content in the SAWE as a function of the quadratic effect was observed $(\mathrm{p}>0.05)$. There was a extraction time and temperature. It was observed that at positive linear effect of extraction time and a negative interaction effect between the extraction time and temperature $(\mathrm{p}<0.05)$ on the protein yield. Figures $1 B$ and $2 \mathrm{~B}$ show the response surface and contour plots of the lower extraction temperature $\left(110^{\circ} \mathrm{C}\right)$, the protein content had considerably increased from 38.2 to 98.1 $\mathrm{mg} / \mathrm{g}$ (based on the equation in Table 4) as extraction time was prolonged from 40 to 130 mins. In contrast, at 
$126^{\circ} \mathrm{C}$, more protein had been extracted at 40 mins $(58.4$ $\mathrm{mg} / \mathrm{g}$ ) and had slightly increased with an extended extraction time (130 mins, $65.1 \mathrm{mg} / \mathrm{g})$. The reduction of the protein content along with the decreases in the reducing sugar and increases in the browning index at high temperatures and longer extraction times (Table 3) could have been due to the formation of products from the Maillard reaction (Tamaoka et al., 1991). Compared to the conventional alkaline extraction, greater proteins were able to be extracted from defatted rice bran at optimal conditions by subcritical alkaline water extraction (Kaewjumpol et al., 2018). Sereewatthanawut et al. (2018) reported that the highest yield of protein $\left(219 \pm 26 \mathrm{mg} / \mathrm{g}\right.$ of dry bran) was obtained at $200^{\circ} \mathrm{C}$ for 30 mins.

\subsection{Antioxidant activity}

Since the model of the FRAP was not reliable and accurate, the result was not discussed. The ABTS radical scavenging activity of the SAWE powders is shown in Table 3, and the plots, illustrating the influence of extraction time and temperature on the ABTS response, are shown in Figures $1 \mathrm{C}$ and $2 \mathrm{C}$. The positive linear effects of both the extraction time and the temperature $(p<0.05)$ indicated that when extraction time and temperature were increased, the ABTS activity had increased. The negative quadratic effect was noted only for the extraction time $\left(x_{1}\right)$ and no interaction effect was seen (Table 4). Generally, the ABTS radical scavenging activity of the SAWE was lower at lower extraction temperatures and times. At higher temperatures, the ABTS value was enhanced as the extraction was increased and then slightly decreased thereafter, which resulted in a curvilinear effect response surface as observed in Figure 1C. Several research studies have reported that subcritical water can extract high amounts of antioxidant compounds, such as phenolic compounds, peptides, and flavonoids as well as generate Maillard reaction products (Kaewjumpol et al., 2018) all of which were identified from the rice bran and had high antioxidant power (Tian et al., 2004; Pourali et al., 2010). Sereewatthanawut et al. (2008) reported that rice bran, which was extracted by subcritical water at $120^{\circ} \mathrm{C}$ for 5 mins, revealed ABTS activity as $\mathrm{IC}_{50}$ of $1.15 \mathrm{mg} /$ $\mathrm{mL}$.

\subsection{Browning index and reducing sugar}

The plots of the experimental values of the browning index and reducing sugar suggested a good fit, as shown in Figures 1D and E, Figures 2D and E, and Table 4. Both extraction time and the temperature had significant positive linear and quadratic effects $(\mathrm{p}<0.05)$ on the browning index. A significant negative interaction effect between the extraction time and the temperature was also observed. At all extraction temperature levels, the browning index had increased along with the extended time, especially at 130 mins (Figure 1D). In contrast, only the (positive) linear and (negative) quadratic effects of the extraction temperature $\left(x_{2}\right)$ were found to be significant for reducing sugar (Table 4). The reducing sugar content, calculated from the model equation, was $28.9-36.5 \mathrm{mg} / \mathrm{g}$ at $110^{\circ} \mathrm{C}$ and $56.5-78.4 \mathrm{mg} / \mathrm{g}$ at $126^{\circ} \mathrm{C}$. However, an extended extraction time depleted the reducing sugar at all temperature levels. The formation of the Maillard reaction products could be responsible for the changes in the browning index and the reducing sugar of the SAWE (Kaewjumpol and Thawornchinsombut, 2018).

\subsection{Yield}

A significant lack of fit $(p=0.0183)$ of yield was observed, which indicated that the model did not adequately fit the experimental data. Overall, it could be noted that yield of the SAWE powder was greater at a high extraction temperature and at a medium range of time. This is probably because subcritical water extraction (SWE) under alkaline condition can extract a greater amount of compounds such as carbohydrates (i.e. sugar), carbohydrate-phenolic complex, polysaccharides (i.e. cellulose, hemicellulose) and starch from rice bran cells (Toor et al., 2011). At higher temperature, the SWE weaken the hydrogen bond due to the increased thermal agitation leading to more efficient extraction of nonpolar compounds than polar compounds (Ko et al., 2014). However, when extraction time is extended, those compounds can be decomposed and/or interact with each other thus decreasing yield. The release of phenolic compounds from potato peel under SWE was significantly affected by temperature (Singh et al., 2011). At high temperatures $\left(140\right.$ to $\left.180^{\circ} \mathrm{C}\right)$, phenolic compounds were greater recovered than at lower extraction temperatures. Nevertheless, at very high temperatures $\left(180\right.$ to $\left.240^{\circ} \mathrm{C}\right)$, lower phenolic compounds content was observed. Degradation of phenolic compounds by pyrolysis and Maillard reaction were discussed.

\subsection{Process optimization}

A multiple response method, called "Desirability", was performed to optimize the mild SAW extraction process. The scores on each of the dependent variables were transformed into desirability scores with a range from 0.0 for 'Undesirable' to 1.0 for 'Very Desirable' (Candioti et al., 2014). The criteria consisted of having the highest TPC and the ABTS scavenging activity, but having a minimal browning index, while also keeping the protein content and reducing sugar in range. The optimal mild SAW extraction conditions in 
the present study were found to be $119^{\circ} \mathrm{C}$ for 85 mins. The desirability for this condition was 0.824 . The maximum TPC, protein content, ABTS, the browning index, and the reducing sugar content, which were predicted by response surface analysis, are shown in Table 5. Figure 3 presents the overlay contour plots of five responses (i.e., TPC, the protein content, ABTS, the browning index, and the reducing sugar). The shaded area shows the RSM optimum conditions for the desirable criteria mentioned earlier.

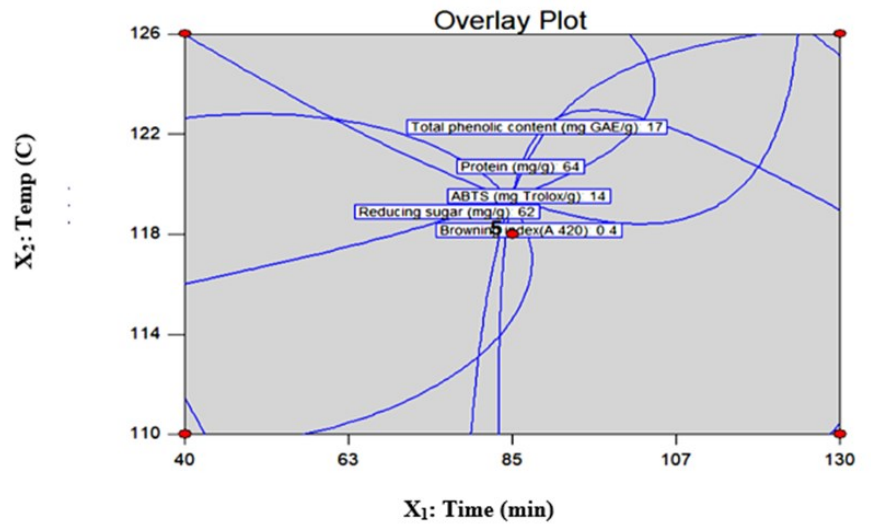

Figure 3. Superimposing contour plots at optimum conditions of the response variables as affected by SAW extraction time and temperature.

\subsection{Verification of the model}

Confirmatory experiments were carried out under the respective optimal SAW extraction time and temperature $\left(119^{\circ} \mathrm{C}, 85 \mathrm{mins}\right)$. The experimental values were found to be relatively close to the predicted values derived from the regression models (Table 4) with the coefficient of variations ranging from $3.37 \%$ to $12.43 \%$ (Table 5). The proximate compositions of the SAWE powder were as follows: $1.88 \%$ moisture, $4.73 \%$ fat, $15.02 \%$ protein, $2.30 \%$ ash, $35.66 \%$ fibre, and $40.41 \%$ carbohydrate.

\subsection{Phenolic profiles of defatted rice bran and SAWE powder}

Qualitative and quantitative analyses of the phenolic compounds in the cold-pressed defatted KDML 105 rice bran (CDRB) and its SAW extract were conducted using the UPLC technique. The type and quantity of each standard phenolic compound are displayed in Table 6 .
Eight phenolic compounds, consisting of trans-ferulic acid, protocatechuic acid, vanillic acid, quercetin, coumaric acid, hydroxy-benzoic acid, syringic acid, and sinapic acid, were found in both the CDRB and the SAWE. They are considered to be major phenolic compounds in rice and rice bran (Tian et al., 2004; Shao et al., 2014; Setyaningsih et al., 2016). High amounts of proto-catechuic acid $(540.5 \mu \mathrm{g} / \mathrm{g})$ and coumaric acid $(123.2 \mu \mathrm{g} / \mathrm{g})$ were found in CDRB, while trans-ferulic acid $(222.9 \mu \mathrm{g} / \mathrm{g})$, proto-catechuic acid $(217.3 \mu \mathrm{g} / \mathrm{g})$, and coumaric acid $(146.9 \mu \mathrm{g} / \mathrm{g})$ were mainly detected in the SAWE. It was interesting to note that the SAW treatment can either increase or degrade the phenolic compounds in the CDRB. After the suspension of CDRB (pH 9.5) had been treated under the optimum SAW conditions $\left(119^{\circ}\right.$ C, 85 mins), trans-ferulic acid was significantly released from the CDRB, which resulted in 9.8 times greater content of trans-ferulic acid in the SAWE than in the CDRB. The amounts of vanillic acid and coumaric acid also increased (3.3 and 1.2 times, respectively). Nonetheless, other phenolic compounds were decomposed, especially the proto-catechuic acid (Table 6). Similar results were reported by Fabian et al. (2010), and dominant phenolic acids, including ferulic acid, $p$ coumaric acid, gallic acid, and caffeic acid, were detected. The reason for this would be the ability of SAW to hydrolyse the phenolic acid in the cell walls or to bind the phenolic compounds from the phenol-protein complex or the phenol-polysaccharide complex interaction (Tabaraki and Nateghi, 2011), such as soluble conjugates with sugar and others molecular such as

Table 6. The phenolic compound profiles of the cold-pressed defatted rice bran (CDRB) and mild-SAW extract (SAWE) analyzed using ultra-performance liquid chromatography (UPLC).

\begin{tabular}{lcc}
\hline \multirow{2}{*}{\multicolumn{1}{c}{ Phenolic acids }} & \multicolumn{2}{c}{ Phenolic acid content $(\mu \mathrm{g} / \mathrm{g})$} \\
\cline { 2 - 3 } & $\mathrm{CDRB}$ & $\mathrm{SAWE}$ \\
\hline Trans-ferulic acid & $22.79 \pm 0.40$ & $222.89 \pm 0.31$ \\
Proto-catechuic acid & $540.49 \pm 0.25$ & $217.25 \pm 1.69$ \\
Vanillic acid & $5.72 \pm 0.42$ & $18.95 \pm 0.51$ \\
Quercetin & $21.97 \pm 0.16$ & $4.81 \pm 0.13$ \\
Coumaric acid & $123.17 \pm 1.44$ & $146.90 \pm 0.45$ \\
Hydroxy-benzoic acid & $39.72 \pm 0.69$ & $22.65 \pm 0.11$ \\
Syringic acid & $3.77 \pm 0.06$ & $2.67 \pm 0.05$ \\
Sinapic acid & $35.09 \pm 0.38$ & $22.92 \pm 0.74$ \\
\hline
\end{tabular}

Values are presented as mean \pm standard deviation $(\mathrm{n}=2)$.

Table 5. Experimental values and predicted values of SAWE obtained under optimal mild-SAW extraction conditions from defatted rice bran and their coefficient of variations.

\begin{tabular}{lccc}
\hline \multicolumn{1}{c}{ Responses } & Predicted value & Experiment value $^{1}$ & Coefficient of variation (\%) $^{\circ}$ \\
\hline Total phenolic content (mg Gallic acid/g) & 16.88 & $15.14 \pm 0.82$ & 7.68 \\
Protein (mg/g) & 64.33 & $68.67 \pm 0.56$ & 4.61 \\
ABTS (mg Trolox/g) & 14.42 & $12.09 \pm 1.48$ & 12.43 \\
Browning index (A420) & 0.41 & $0.43 \pm 0.12$ & 3.37 \\
Reducing sugar (mg/g) & 61.98 & $57.90 \pm 0.21$ & 4.81 \\
\hline
\end{tabular}

${ }^{1}$ Results were expressed as mean \pm standard deviation $(\mathrm{n}=2)$ 
lignin, pectin, cellulose, and hemicellulose (Vichapong et al., 2010). Under subcritical or hydrothermal conditions, alkaline water has a low viscosity and a high solubility of organic substances (Kruse and Dinjus, 2007; Fabian et al., 2010; Toor et al., 2011).

In addition to the amount, the type of phenolic compound in the SAWE is important regarding antioxidant capacity. Shao et al. (2018) found positive correlations between TPC and antioxidant activity $(\mathrm{P}<$ 0.01) among the non-pigmented, red, and black rice varieties. Moreover, protocatechuic, vanillic, syringic and ferulic acids had positive correlations with TPC and antioxidant activity in the extracts from various rice varieties. In the present study, trans-ferulic acid and proto-catechuic acid were mainly detected in the SAWE thus might being responsible for its antioxidant capacity.

\section{Conclusion}

Optimization of the antioxidant extraction conditions applied to the cold-pressed defatted KDML105 rice bran using the mild SAW technology was successfully performed. By using response surface methodology, the maximum values for the antioxidant compounds and activity but the minimal browning index were achieved at $119^{\circ} \mathrm{C}$ for 85 mins as the optimum conditions for mild SAW extraction. Different profiles of phenolic compounds were markedly noticeable in the CDRB and its SAW extract. The mild SAW extraction efficiently extracted trans-ferulic acid from the CDRB but degraded some phenolic compounds, especially proto-catechuic acid. The results confirm that the mild SAW extraction is an environmentally friendly approach, which can considerably increase the release of value-added compounds from rice bran residues.

\section{Conflict of interest}

The authors declare no conflict of interest.

\section{Acknowledgments}

The authors wish to express their gratitude for the financial support received from the Budget Research Grant of the Doctoral Research Scholarship from the Surin Campus of the Rajamangala Isan University of Technology in Thailand. This research was also supported by Research and Technology Transfer Affairs, Khon Kaen University (2017).

\section{References}

AOAC. (2000). Official Methods of Analysis of AOAC. International Arlington, USA: AOAC.

Bas, D., Ismail, H. and Boyaci, I.H. (2007). Modeling and optimization, I: Usability of response surface methodology. Journal of Food Engineering, 78(3), 836-845. https://doi.org/10.1016/j.jfoodeng. 2005.11 .024

Belwal, T., Dhyaniaindra, P., Ranbeer, B., Rawala, S. and Pande, V. (2016). Optimization extraction conditions for improving phenolic content and antioxidant activity in Berberis asiatica fruits using response surface methodology (RSM). Food Chemistry, 207, 115-124. https://doi: 10.1016/ j.foodchem.2016.03.081

Candioti, L.V., De Zan, M.M., Cámara M.S. and Goicoechea, H.C. (2014). Experimental design and multiple response optimization. Using the desirability function in analytical methods development. Talanta, 124, 123-138. https://doi: 10.1016/j.talanta.2014.01.034

Dong, S., Wei, B., Chen, B., Mcclements, D.J. and Decker, E.A. (2011). Chemical and antioxidant properties of casein peptide and its glucose Maillard reaction products in fish oil-in-water emulsions. Journal of Agricultural and Food Chemistry, 59(24), 13311-13317. https://doi: 10.1021/jf203778z

Fabian, C., Tran- Thi, N.Y., Kasim, N.S. and Ju, Y.H. (2010). Release of phenolic acids from defatted rice bran by subcritical water treatment. Journal of the Science of Food and Agriculture, 90(15), 25762581. https://doi: 10.1002/jsfa.4123

Jin, F. (2014). Application of Hydrothermal Reactions to Biomass Conversion. Berlin, Germany: Springer. https://doi.org/10.1007/978-3-642-54458-3

Kaewjumpol, G., Oruna-Concha, M.J., Niranjan, K. and Thawornchinsombut, S. (2018). The production of hydrolysate from industrially defatted rice bran and it surface image change during extraction. Journal of the Science of Food and Agriculture, 98(9), 32903297. https://doi.org/10.1002/jsfa.8832

Kaewjumpol, G. and Thawornchinsombut, S. (2018). Enhanced storage stability of freeze dried rice bran hydrolysates by maltodextrin. Asia-Pacific Journal of Science and Technology, 23(2), 1-11. https:// doi.org/10.14456/kkurj.2018.5.

Ko, M.J., Cheigh, C.I. and Chung, M.S. (2014). Relationship analysis between flavonoids structure and subcritical water extraction (SWE). Food Chemistry, 143, 147-155. https://doi.org/10. 1016/ j.foodchem.2013.07.104

Kruse, A. and Dinjus, E. (2007). Review Hot compressed water as reaction medium and reactant: Properties and synthesis reactions. The Journal of Supercritical Fluids, 39(3), 362-380. https:// doi.org/10.1016/j.supflu.2006.03.016 
Li, X., Xiong, H., Yang, K., Peng, D., Peng, H. and Zhao, Q. (2012). Optimization of the biological processing of rice dregs into nutritional peptides with the aid of trypsin. Journal of Food Science and Technology, 49(5), 537-546. https:// doi 10.1007/ s13197-011-0303-6

Liyana-Pathirana, C. and Shahidi, F. (2005). Optimization of extraction of phenolic compounds from wheat using response surface methodology. Food Chemistry, 93(1), 47-56. https://doi.org/ 10.1016/j.foodchem.2004.08.050

Lowry, O.H., Rosebrough, N., Farr, A.L. and Jandall, R.J. (1951). Protein measurement with the Folin phenol reagent. Journal of Biological Chemistry, 193 (1), 265-275. https://doi.org/10.1016/S0021-9258 (19)52451-6

Munir, M., Kheirkhah, H., Baroutian, S., Quek, S.Y. and Young, B.R. (2018). Subcritical water extraction of bioactive compounds from waste onion skin. Journal of Cleaner Production, 183, 487-494. https:// doi.org/10.1016/j.jclepro.2018.02.166

Nelson, N. (1944). A photometric application of the Samogi method for the determination of glucose. Journal of Biological Chemistry, 153(2), 375-380. https://doi.org/10.1016/S0021-9258(18)71980-7

Pourali, O., Asghari, F.S. and Yoshida, H. (2009). Subcritical water treatment of rice bran to produce valuable materials. Food Chemistry, 115(1), 1-7. https://doi.org/10.1016/j.foodchem.2008. 11.099

Sereewatthanawut, I., Prapintip, S., Watchiraruji, K., Goto, M., Sasaki, M. and Shotipruk, A. (2008). Extraction of protein and amino acids from deoiled rice bran by subcritical water hydrolysis. Bioresource Technology, 99(3), 555-561. https://doi: 10.1016/j.biortech.2006.12.030

Setyaningsih, W., Saputro, I.E., Palma, M. and Barroso, C.G. (2016). Pressurized liquid extraction of phenolic compounds from rice (Oryza sativa) grains. Food Chemistry, 192, 452-459. 10.1016/j.foodchem.2015.06.102

Shao, Y., Xu, F., Sun, X., Bao, J. and Beta, T. (2014). Identification and quantification of phenolic acids and anthocyanins as antioxidants in bran, embryo and endosperm of white, red and black rice kernels (Oryza sativa L.). Journal of Cereal Science, 59(2), 211-218. https://doi.org/10.1016/ j.jcs.2014.01.004

Shao, Y., Hu, Z., Yu, Y., Mou, R., Zhu, Z. and Beta, T. (2018). Phenolic acids, anthocyanins, proanthocyanidins, antioxidant activity, minerals and their correlations in non-pigmented, red, and black rice. Food Chemistry, 239, 733-741. https:// doi.org/10.1016/j.foodchem.2017.07. 009
Singh, P.P. and Saldaña, M.D.A. (2011). Subcritical water extraction of phenolic compounds from potato peel. Food Research International, 44(88), 24522458. https://doi.org/10.1016/j.foodres. 2011.02.006

Somogyi, M. (1952). Notes on sugar determination. Journal of Biological Chemistry, 195(1), 19-23. https://doi.org/10.1016/S0021-9258(19)50870-5

Sompong, S., Siebenhandl-Ehn, S., Linsberger-Martin, G. and Berghofer, E. (2011). Physicochemical and antioxidative properties of red and black rice varieties from Thailand, China and Sri Lanka. Food Chemistry, 124(1), 132-140. https://doi.org/10.1016/ j.foodchem.2010.05.115

Tabaraki, R. and Nateghi, A. (2011). Optimization of ultrasonic-assisted extraction of natural antioxidants from rice bran using response surface methodology. Ultrasonics Sonochemistry, 18(6), 1279-1286. https://doi: 10.1016/j.ultsonch.2011.05.004

Tamaoka, T., Itoh, N. and Hayashi, R. (1991). High pressure effect on Maillard reaction. Agricultural and Biological Chemistry, 55(8), 2071-2074. https:// doi.org/10.1080/00021369.1991.10870919.

Thai Rice Exporters Association. (2019). Retrieved on August 15, 2019 from Thai Rice Exporters Website: http://www.thairiceexporters.or.th/ default_th.htm.

Thaipong, K., Boonprakob, U., Crosby, K., Zevallos, L.C. and Byrne, D.H. (2006). Comparison of ABTS, DPPH, FRAP, and ORAC assays for estimating antioxidant activity from guava fruit extracts. Journal of Food Composition and Analysis, 19(1617), 669-675. https://doi:10.1016/j.jfca. 2006.01.003

Tian, S., Nakamura, K. and Kayahara, H. (2004). Analysis of phenolic compounds in white rice, brown rice, and germinated brown rice. Journal of Agricultural and Food Chemistry, 52(15), 48084813. https://doi: 10.1021/jf049446f

Toor, S.S., RosendahL, L. and Rudolf, A. (2011). Hydrothermal liquefaction of biomass: A review of subcritical water technologies. Energy, 36(5), 23282342. https://doi.org/10.1016/j.energy. 2011.03.013

Vichapong, J., Sookserm, M., Srijesdaruk, V., Swatsitang, P. and Srijaranai, S. (2010). High performance liquid chromatographic analysis of phenolic compounds and their antioxidant activities in rice varieties. LWT- Food Science and Technology, 43(9), 1325-1330. https:// doi.org/10.1016/j.lwt.2010.05.007

Wataniyakul, P., Pavasant, P., Goto, M. and Shotipruk, A. (2012). Microwave pretreatment of defatted rice bran for enhanced recovery of total phenolic compounds extracted by subcritical water. Bioresource Technology, 124, 18-22. https://doi: 
10.1016/j.biortech.2012.08.053

Wiboonsirikul, J., Kimura, Y., Kanaya, Y., Tsuno, T. and Adachi, S. (2008). Production and characterization of functional substances from a byproduct of rice bran oil and protein production by a compressed hot water treatment. Bioscience Biotechnology and Biochemistry, 72(2), 384-392. https://doi: 10.1271/bbb.70464

Yang, E-H. and Wang, L. (2012). Method, system and computer program product for optimization of data compression with cost function. US Patent No. 8194990B2. Retrieved from website: https:// patentimages. storage.googleapis.com/76/49/0c/ d3849ed1dfd4ad/US8194990.pdf.

Yodmanee, S., Karrila, T.T. and Pakdeechanuan, P. (2011). Physical, chemical and antioxidant properties of pigmented rice grown in Southern Thailand. International Food Research Journal, 18(3), 901906.

Zhang, M.W., Zhang, R.F., Zhang, F.X. and Liu R.H. (2010). Phenolic profiles and antioxidant activity of black rice bran of different commercially available Varieties. Journal of Agricultural and Food Chemistry, 58(13),7580-7587. https://doi: 10.1021/ jf1007665 